\title{
Integrated Islamic Elementary School Characteristics as Encouragement for Parents in Choosing Education for Children
}

\author{
Muhammad Ridho Nugroho* and Muhammad Kristiawan
}

\author{
Doctor of Education Program Study, University of Bengkulu \\ *Corresponding author. Email: muhammad.ridho74@ui.ac.id
}

\begin{abstract}
The parents will then be faced with multiple primary school options after their children finished the education at the preschool level, which will be taken as a continuation of the next level of education. One of the options for parents to continue their children's education is Integrated Islamic Elementary Schools (SDIT). Any of the benefits of an Integrated Islamic Elementary School (SDIT) institution provides make parents comfortable in sending their children into this institution. The goal of this analysis was to see the characteristics of SDIT, which are the main incentive for parents to choose their children's education. This research is a quantitative descriptive study by administering questionnaires to the parents of students at SDIT Raudhatul Jannah Lubuklinggau up to 60 respondents. Data collection was using a survey approach with a rating scale questionnaire instrument. The results of the study showed that the features of Integrated Islamic Elementary Schools (SDIT) that inspire parents to choose the education for their children are the memorization program of the holy Qur'an about $93 \%$ respondent, integration of general and religious educations about $78 \%$ respondent, good facilities and amenities about $45 \%$ respondent, extracurricular activities about $22 \%$ respondent, fullday school about $20 \%$ respondent, and high costs about $2 \%$ respondent. The Quran memorization program is a feature of integrated Islamic primary schools that is the most dominant incentive for parents to choose education for their children.
\end{abstract}

Keywords: Motivation, Basic education, Integrated Islamic elementary school.

\section{INTRODUCTION}

Education is a service in the form of a civilizing method, with input and output implied by this definition. The students, equipment, facilities, and the environment are inputs, while educational programs, graduates or alumni, and study results are theproduct. In this case, the education services are services offered by the education manager to those directly accessing certain services in compliance with certain quality requirements [1].

In recent years, many educational institutions have emerged with the idea of education as a service in the form of integrated Islamic schools that combine general education and religious education as a superior idea. It is followed by the fulfillment of the best facilities and services for students, so that the schools are not only the educational institutions, but also educational services that offer a variety of services, facilities and other incentives that influence parents' interest in selecting their children's education.
There are important changes concerning to the pattern of education (read Islamic education) in Indonesia towards the 21 st century. The domination of schools consisting of boarding school, Madrasah and Islamic schools has started to change. The phenomenon of the introduction of Integrated Islamic Schools throughout the world suggests this. Although the Integrated Islamic School is a new one for education sector in Indonesia, but this institution has given new color to the evolution of educational discourse in Indonesia [2].

An Integrated Islamic School is described in its application as a school that implement an approach by incorporating general education and religious education into a curriculum. In order to enhance the cognitive, affective and conative or psychomotor dimensions, Integrated Islamic schools also emphasize convergence in learning methods. Aqliyah (based on the argument), theological and religious education are also combined at the Integrated Islamic School. It incorporates engagement and active involvement in learning environments, namely classrooms, homes and neighborhoods [3]. 
By those understanding, it can be understood that the Integrated Islamic schools are the Islamic schools which is organized by incorporating Islamic values and teachings in the curriculum. It is built with an effective learning approach, optimal and cooperative participation between teachers and parents, as well as the community to promote the character and student competitions [3].

In this context, the Islamic schools are the schools or private educational institutions that put Islam as the foundation of the education [4]. In general, Islamic foundations and organisations, such as Muhammadiyah, Nahdatul Ulama, Hidayatullah, Al-Irsyad, and others, coordinate this model of educational institutions. Islamic schools are a further evolution of the Dutch school system when seen from a historical perspective. For the first time since the organization was established, Muhammadiyah implemented the system by taking over the Dutch school system and introducing Islam as a compulsory subject [5].

\subsection{SDIT Emerging Trend}

The trend has been established since the advent of integrated Islamic schools today. Housing these schools as a platform for information and collaboration between schools. The Integrated Islamic School Network (JSIT) and the Association of Indonesian Sunnah Schools (ASESI) as home to several integrated Islamic schools in Indonesia among the organizations were created. About 1,000 Integrated Islamic Schools are members of the Integrated Islamic School Network (JSIT) that management is well established in Indonesia, and about 10,000 Integrated Islamic Schools are not structurally integrated under JSIT. [3].

Thus indicate that the broader community received such an enthusiastic response to the establishment of the Integrated Islamic School. This strong public reaction is due to the most Indonesians' discontent with established educational institutions, including Islamic boarding schools, madrasahs, and (general) schools. The community needs an educational institution that can provide the students with sufficient arrangements to face the difficulties of formidable innovations. The different events involving juvenile delinquency, such as student brawls, intoxication, the use of dangerous substances, and promiscuity, are causing such great concern about their children's future. Therefore, it is important to provide an educational institution that incorporates modern education, so that the children can still adapt to changes in the modern world, but still have a strong religious base as a basis for moral formation, so that they are not carried away and that the changes of the period have a negative effect. The Integrated Islamic School seems to have been born as a response to these diverse demands and problems [2].
There are many integrated Islamic elementary schools in Lubuklinggau City under the auspices of the Education and Culture Office of Lubuklinggau City. In 2012, the advent of this integrated Islamic elementary school began. In the field of education, the presence of SDIT is a modern breakthrough, offering its own characteristics and features, such that SDIT has a format that separates it from other primary schools. These features enable parents to enter these educational institutions with different considerations, including the convergence of curricula between general education and religious education, the presence of a memorization program for the holy Qur'an, good facilities, extracurricular activities, high costs and full-day school programs.

\subsection{Previous Research Results}

There are four factors that affect the perceptions of parents in choosing education services at SDIT, namely facilities, quality, school cost and location based on the findings of Nurul Andini 's study. These four variables have a significance level of $<0.05$, which suggests that these four variables have a positive influence on the preferences of parents in the choice of educational services at SDIT [1].

The research findings by Rizka Nur Laila Dewi clarified showed that intrinsic factors and extrinsic factors caused the motivation of parents to select a religion-based school. Intrinsic factors in the motivation of parents in order to get the highest percentage to the smallest factors, namely: (1) to have a noble character, (2) to understand religious fiqh, (3) to understand the Qur'an, (4) to have knowledge of religion, and (5) to have positive achievements. While, the extrinsic factors of the motivation of parents are in the order of the factors that obtained the largest to the smallest percentage were: (1) school order, (2) religious education section, (3) educator profile, (4) school vision and mission, (5) alternative activities, (6) scholastic abilities, (7)) curriculum for learning, (8) physical facilities, (9) school location and atmosphere, (10) family support, (11) community support, and (12) costs. The main factor in the intrinsic motivation of parents to send their children to school is the noble character factor, with a $90 \%$ figure. While the dominant extrinsic incentive factor for parents to send to school on the basis of the scale firmly agrees, the school order factor with a 76 percent percentage of [6]. On the basis of some of the above research findings, the author wants to see what dominant variables inspire parents at SDIT Raudhatul Jannah Lubuklinggau to choose education for their children. 


\section{METHOD}

This analysis is a quantitative descriptive study with a rating scale questionnaire instrument by using a survey process. The location of the research was at the Raudhatul Jannah Lubuklinggau Islamic Elementary School, with total sampel was 60 student guardians. By considering the Covid-19, the questionnaire was distributed through a Google form, through the student guardians' WhatsApp communityon October 2020. The questionnaire was given in 6 questions with the following indicators: curriculum, qur'an memorization program, extra-curricular, infrastructure, fees, full day school. The data were analyzed by adding up all the answers then calculating the percentage of each indicator. The goal of this research was to find out the dominant characteristics of SDIT, which are the greatest incentive for parents to choose their children's education.

\section{BACKGROUND}

Schools are part of education that is held to prepare individuals to develop abilities and apply their skills in order to establish themselves to be useful for themselves, for families, communities and the State with the discipline that exists in school education. In the school education environment, there are rules and sanctions that apply to implementing a good personality so that it is useful for individuals and the public, as well as an example for others in obeying and obeying the rules in society [7]. When times are growing, parents are increasingly required to become parents who must have a special strategy for the future of their children. Parents want to see their children become independent and successful individuals for those closest to them. Therefore it is important for parents to plan their child's education. Parents are worried about the negative impact of the times trying to find solutions through educational institutions that are able to overcome various problems that make them worried. Nowadays there are many integrated schools emerging, some of which use the Islamic foundation as a basis in the educational process and some are not related to this [8].

Integrated Islamic schools predominantly prioritize character education as their trademark, so that with early character education children are trained to be able to have superior and tough personalities in facing challenges in the era of globalization. Character education is everything that the teacher does, that is able to influence the character of students. Teachers help shape the character of students. Character education instills habits about things which one is good so that students understand which one is correct and wrong, able to feel good value and get used to doing it. On period of elementary school children, the method the teacher used for developing character is direction, habituation, exemplary, reinforcement, punishment. Character values that can be explored in learning such as religious, honest, hard work, discipline, sense of responsibility, love for the country, care for the environment, a strong social spirit [9].

\section{DISCUSSION}

A rating scale questionnaire was the instrument used in this analysis. Sukmadinata (2010) states that the descriptive scale follows the form of a likert attitude scale in the form of questions or statements. In answering the questionnaire, the respondent's response in the form of an acceptance or disapproval scale and are strongly articulated in agreement, agreement, disagreement, and strongly disagreement [10].

The answer group is firmly in agreement with score $=4$, in agreement with score $=3$, in agreement with score $=2$ and in clear disagreement with score $=1$. Of the 60 respondents who replied to the questionnaire sent to the guardians of the students of SDIT Raudhatul Jannah Lubuklinggau, the findings were as follows:

Table 1. The number of parents who select SDIT education based on their features

\begin{tabular}{|l|c|c|c|c|c|}
\hline \multirow{2}{*}{ Characteristics } & \multicolumn{4}{c|}{ Answer Category } & \multirow{2}{*}{ Amount } \\
\cline { 2 - 5 } & $\mathbf{1}$ & $\mathbf{2}$ & $\mathbf{3}$ & $\mathbf{4}$ & 60 \\
\hline $\begin{array}{l}\text { Integration of general and religious } \\
\text { educations }\end{array}$ & 0 & 0 & 13 & 47 & 60 \\
\hline Alqur'an memorization program & 0 & 0 & 4 & 56 & 60 \\
\hline Extracurricular activities & 0 & 3 & 44 & 13 & 60 \\
\hline Good facilities and infrastructure & 0 & 1 & 32 & 27 & 60 \\
\hline High costs & 8 & 40 & 11 & 1 & 60 \\
\hline Full day school program & 0 & 10 & 38 & 12 & \\
\hline
\end{tabular}


Based on table 1, the number of parents who selected each factor from a rating scale of 1-4 can be seen, there were 47 parents who preferred education at SDIT based on the features of the integration of general education and religious education, 56-person chosen based on the features of the Qur'an memorization program, 13 parents chosen based on the characteristics of out-of-school activities, 27 people chosen based on the characteristics of good facilities and amenities, 1 person chosen based on the characteristics of high costs, and 12 people chosen based on the characteristics of full-day schooling. The researcher can concentrate on data analysis only on a score of 4 , which is on a highly accepted scale, through this data.

In addition, in table 2, the effects of determining the percentage of each factor can be shown as follow:

Table 2. Percentage of parents preferring SDIT education based on their features

\begin{tabular}{|l|c|c|c|c|c|}
\hline \multirow{2}{*}{ Characteristics } & \multicolumn{4}{|c|}{ Percentage (\%) } & \multirow{2}{*}{ Amount } \\
\cline { 2 - 5 } & $\mathbf{1}$ & $\mathbf{2}$ & $\mathbf{3}$ & $\mathbf{4}$ & 100 \\
\hline $\begin{array}{l}\text { Integration of general and religious } \\
\text { educations }\end{array}$ & 0 & 0 & 22 & 78 & \\
\hline Alqur'an memorization program & 0 & 0 & 7 & 93 & 100 \\
\hline Extracurricular activities & 0 & 5 & 73 & 22 & 100 \\
\hline Good facilities and infrastructure & 0 & 2 & 53 & 45 & 100 \\
\hline High costs & 13 & 67 & 18 & 2 & 100 \\
\hline Full day school program & 0 & 17 & 63 & 20 & 100 \\
\hline
\end{tabular}

Based on table 2, parents who choose education at SDIT based on the characteristics of the integration of general education and religious education is $78 \%$, based on the characteristics of the Qur'an memorization program is $93 \%$, based on the characteristics of extracurricular activities is $22 \%, 45 \%$ based on the basis of good facilities and infrastructure characteristics, $2 \%$ based on the basis of high cost characteristics, and 20 percent based on the basis of full-day school features. It is understood that scale of 4 is quite agreeable.

By looking at the current motives of these parents, the motivation of parents in deciding the school can be investigated. With this encouragement, parents then have an opportunity to take action and eventually make a choice or behavior by selecting the best school for their children. [6]. It can be sorted from the most dominant to the lowest motivation from the findings is the reasons of parents in chosing SDIT education for their children are explain below.

\subsection{Quran Memorization Program}

The idea that is given by an integrated Islamic school really helps students to improve their academic and religious skills. Some schools also give the target to the students with the memorization of $5 \mathrm{Juz}$ Al-quran. Among the superior programs provided by integrated Islamic schools, namely the alquran memorization program either with one day one juz method, one day one verse or the tasmi' wa takrir method.

With this outstanding program, the parents are more encouraged in teaching their children the holy Koran that is not found in the ordinary public schools, and some parents who send their children to these public schools must provide their children with additional time at the Alqur'an Education Institution to learn the holy
Koran. In the afternoon, that is called 'an (TPA). Meanwhile, their parents usually only obtain memorization or muraja'ah at home for children who attend integrated Islamic schools.

The results of the survey showed that the most dominant motivation, which was $93 \%$, was the motivation of parents to send their children to SDIT because of the Quran memorization program. The qur'an memorization program is a favorite program offered by many Islamic schools today, so that it is a characteristic of the school that makes parents interested. About 30 students have memorized at least one juz at SDIT Raudahtul Jannah Lubuklinggau, while more than 10 students have memorized between 3 and 4 juz mutqin for grade 6 .

\subsection{Integration of General and Religious Education}

On the basis that they want to shape the character of their children who master science and technology, and iman and taqwa (faith and piety), parents are more likely to choose their children's education in integrated Islamic schools. A balance between general science and religious knowledge is formed by integrating general and religious curricula. The survey results indicate that the second incentive for $78 \%$ is the incentive of parents to send their children to SDIT because of the integration between general education and religious education.

The features of an integrated Islamic school above are a justification for parents to send their children to an integrated Islamic school in the hope that their children not only master different fields of academic science, but also be matched with their knowledge in the field of religious science so that there is harmony in ways, ahlaq (morals), and the child's character is in line with the parents hope to shape their children into pious, intelligent and superior children. 
Emotional intelligence is not everything that makes a person successful, because emotional intelligence without involving the function of Spiritual Intelligence (SQ) in a person will be frightening, and this SQ is a guide and radar scanner of the heart so that actions from attitude can be done more wisely and wisely to direct to divine truth which functions in his conscience. When a person's emotions run well, his spiritual conscience is alive and open to accept the truth, and is free from bondage and arrogance and anger [11].

\subsection{Facilities and Infrastructure}

It is known from the study that the encouragement of parents towards SDIT features with good facilities and infrastructure is $45 \%$. Several integrated Islamic schools run by a foundation typically provide good facilities, ranging from shuttle facilities, catering, airconditioned classrooms, etc., for students and student guardians.

Another reason for parents to choose schools for their children is the best services and facilities provided by the implementation of education in integrated Islamic schools, since good services and facilities are required in education, particularly for parents with high income levels. With good facilities, it is hoped that children can participate in the learning process optimally and comfortably so that it can affect the quality and success of children's education.

\subsection{Extracurricular Activities}

The extra-curricular program give contribution as much as $22 \%$ to motivate the parents to send their children to SDIT. In addition, to provide a general education and religious education, integrated Islamic schools also offer students extracurricular activities, including outing class activities, swimming sports, archery, cooking class, gardening, market day, etc., which are in line with the idea of crossover learning, that is, integrating classroom learning with field learning to stimulate student interest and enthusiasm for learning.

\subsection{Fullday School}

Study hours at integrated Islamic schools are longer, with learning hours beginning from 07.15 to 16.00 for integrated Islamic schools, with duration of 8 hours of lessons plus a 1 hour afternoon break. The urban middle class and busy working parents get profit from the fullday school scheme. In this scheme, they don't need a lot of money to provide for their families by sending their kids to colleges. They don't even have to think about the after-school things their kids do because the kids are complete at school until the afternoon when the parents come home from work and return home. When parents are disturbed by worries about moral harm in the younger generation, whether due to drug use, violence or promiscuity, this is seen as an alternative remedy. For extra-curricular activities which averaged no more than 600,000 rupiah per month, they only need to pay a little extra money. As a result of the full day school scheme, this number is significantly more costly compared to most schools [12].

In this report, it is recognized that $20 \%$ of parents are encouraged to send their children to SDIT on the basis of the full-day school program, with 12 respondents strongly agreeing, 38 agreeing and 10 disagreeing. There are some parents who disagree with the full-day school program because of exhaustion in children who have to do things all day long so that the children can no longer do things when they come home because during school they have been careless.

\subsection{High Costs}

The findings of the study indicated that parents' incentive to select SDIT education for their children is due to $2 \%$ of high school fees. This shows that SDIT's high school fees are not a concern for parents when sending their kids to school. The comparison is far from over as applied to the cost of tuition in public primary schools, and indeed most public elementary schools waive school fees for pupils. Integrated Islamic schools have developed higher enrollment fees and tuition fees on the funding side than general schools. Tuition fees above Rp are paid by certain colleges, with an entry fee of over 5 million rupiah a month, 300,000 a month.

The cost factor would not be a burden, when they see their kids being righteous kids and have noble values. Parents' dream of making their children have noble values is much greater than the cost they have to pay. The most important thing for them is that their sons and daughters are children of noble character and have religious understanding [6].

\section{CONCLUSION}

Because of the Quran memorization program, the characteristic of SDIT is the greatest incentive for parents to send their children to SDIT. It is hoped that the SDIT Raudhatul Jannah educational institution will achieve the goal of the promised student graduation requirements, which is to memorize quran at least 3-4 juz while studying at SDIT Raudahtul Jannah Lubuklinggau, with the greatest motivation of parents for this Quran memorization program.

\section{ACKNOWLEDGMENT}

Thank you to Raudhatul Jannah Lubuklinggau, head of the Islamic Education Institute, and to the parents of the students who provided the data needed for this survey. 


\section{REFERENCES}

[1] Andini, Analisis Pengaruh Persepsi Terhadap Keputusan Orang Tua Murid Memilih Jasa Pendidikan Di Sdit Bina Insani Semarang. Semarang: Fakultas Ekonomi Universitas Diponegoro, 2010.

[2] Suyatno, Sekolah Islam Terpadu; Filsafat, Ideologi, dan Tren Baru Pendidikan Islam di Indonesia. Jurnal Pendidikan Islam, 2013 p 356-377.

[3] JSIT, 2016. https://jsit-indonesia.com/. Retrieved Oktober 5, 2020, from https://jsit-indonesia.com/: https://jsit-ind

[4] Zainal Arifin, Pengembangan Manajemen Mutu Kurikulum Pendidikan Islam, Yogyakarta:Diva Press, 2012, 29.

[5] Widyowati, Lilis, Pengembangan Kurikulum Terpadu Sistem Fullday School (Studi Multi Kasus di SD Muhammadiyah 1 Alternatif Kota Magelang, SDIT Ihsanul Fikri Kota Magelang dan SD Terpadu Ma'arig Gunung Piring Magelang), Program Pascasarjana Sekolah Tinggi Agama Islam Negeri Salatiga, 2014.

[6] Dewi, R. N. Motivasi Orang Tua Memilih Sekolah Berbasis Agama di MI Tahassus Prapag Kidul Kecamatan Pituruh Kabupaten Purworejo. Yogyakarta: Program Studi Pendidikan Guru Sekolah Dasar Fakultas Ilmu Pendidikan Universitas Negeri Yogyakarta, 2015.
[7] Rahmat Ramadhan. Motivasi Anak Memilih Sekolah Di Pesantren Modern Al-Amin Desa Rawang Kao Kecamatan Lubuk Dalam Kabupaten Siak. JOM FISIP. Vol 3 No 2, Oktober 2016.

[8] Nita Safitri. Motivasi Orang Tua memilih Pendidikan Dasar Anak di MIN 1 Batang. Fakultas Tarbiyah dan Ilmu Pendidikan IAIN Pekalongan, 2019.

[9] Dini Palupi Putri. Pendidikan Karakter Pada Anak Sekolah Dasar di Era Digital. Ar-Riayah, Jurnal Pendidikan Dasar, Vol 2 No 1, 2018.

[10] Nana Syaodih Sukmadinata. Metode Penelitian Pendidikan. Bandung: Remaja Rosdakarya, 2010.

[11] Sriani, Urgensi keseimbangan IQ, EQ, SQ Pendidik dalam Proses Manajemen Pembelajaran, Jurnal Nur El Islam, Volume 2 Nomor 1, April 2015.

[12] Hasan, Noorhaidi, Islamist Party, Electoral Politics and Da'wa Mobilization Among Youth: The Prosperous Justice (PKS) in Indonesia, Artikel Online di S.Rajaratnam School of International Studies Singapore, 2008. 